\title{
The Implementation of Critical Thinking in a Saudi EFL Context: Challenges and Opportunities
}

\author{
Budor Saeed Al Zahrani (Correspondence) \\ English Language Institute, King Abdulaziz University, \\ Jeddah, Saudi Arabia \\ e-mail: bsalzahrani@kau.edu.sa \\ Tariq Elyas \\ European Languages Department, King Abdulaziz University, \\ Jeddah, Saudi Arabia
}

\begin{abstract}
:
The aim of this paper is to explore the challenges to, and benefits of, fostering of critical thinking (CT) in the Saudi EFL (English as a foreign language) context. Nowadays, the responsibility of educational institutions is to equip individuals with the essential skills to achieve success in their lives and to facilitate success for their communities. CT skills are amongst the skills most in demand and most needing to be acquired and improved by learners. The paper addresses the concept of CT from and Islamic versus CT from Western perspectives, also, possible challenges or barriers to $C T$, whether religious or pedagogical, in the Saudi context are analyzed and refuted. Finally, practices for promoting CT inside EFL classrooms are described within Saudi context and the benefits of incorporating CT strategies into language learning are outlined.
\end{abstract}

Keywords: critical thinking, EFL, Islamic philosophy, western philosophy, pedagogy, classroom practices 


\section{Introduction}

With the current plethora of knowledge resources, the traditional educational environment is inevitably changing. Rapid developments in the field of technology, whether online or offline, have paved the way to convenient and fast access to information. Students can fetch information and learn about anything from anywhere at any time. For example, they can search for the meaning of any vocabulary item instantly and they will find many related types of information, such as word meaning, synonyms or antonyms, and pictorial or audio representations. Such a transition has resulted in a huge shift in the roles played by the entities involved in the educational process, mainly teachers and students. Teacher-centered classrooms, where the teacher plays the main role, representing the only source of information, are becoming less common. In line with this, students are playing a more active role in their own learning. Thus, a teacher's role must be redefined. The new roles of a teacher should include, among others, improving students' educational and life skills, particularly, students' thinking skills.

Much effort has been dedicated by teachers, education experts and business leaders to arriving at a description of the skills and knowledge students must obtain in order to achieve success and survive in the $21^{\text {st }}$ century. As a result, a "Framework for $21^{\text {st }}$ Century Learning" has been created and has been used by many educators and educational institutes in many parts of the world (P21 Partnership for $21^{\text {st }}$ Century Learning, 2009). One of the most targeted learning skills is critical thinking skill or fluency. This is considered one of the " $4 \mathrm{Cs}$ "- essential skills in this century, namely, critical thinking, communication, collaboration and creativity. The framework's components are illustrated -in Figure (1).

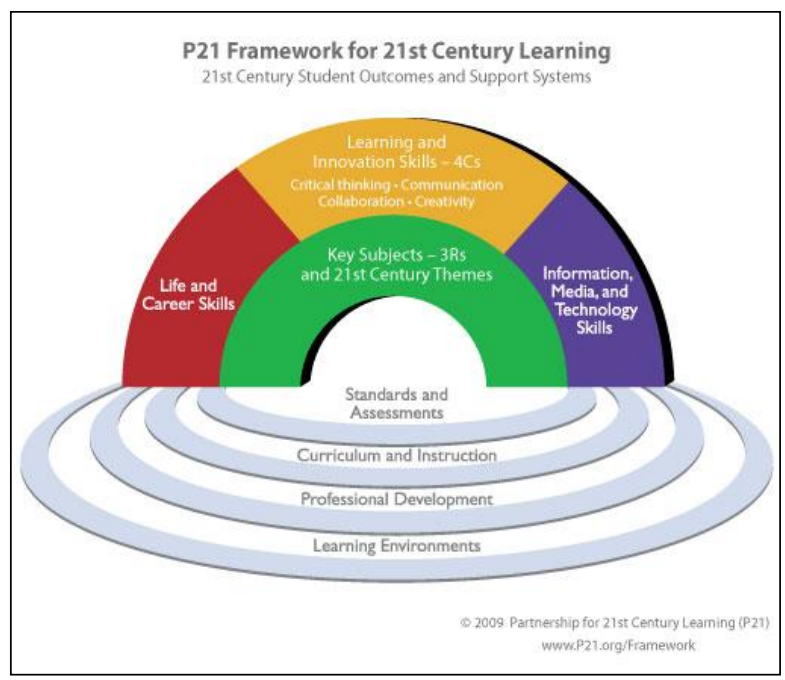

Figure (1): The Framework for $21^{\text {st }}$ Century Learning components http://www.p21.org/about-us/p21-framework 


\section{Defining Critical Thinking}

There is no single definition that has been agreed upon the term "critical thinking." Various definitions have been proposed by experts and researchers in the fields of education and psychology. However, we can trace its beginning to the attempts at investigating the cognitive processes underlying learning by Bloom (1956, cited in Bender, 2003).

Based on the well-known taxonomy of cognitive skills named after him, Bloom classified six types of thinking. He considered three of these types to be lower order thinking skills, namely, knowledge, comprehension and application (referred to as LOTs) and the other three to be higher order thinking skills, namely, analysis, synthesis and evaluation (referred to as HOTs). Some scholars have related the term of "critical thinking" to HOTs (Ennis, 1996; Beyer, 1988). Other scholars have expanded its meaning to include decision-making (Dawes, 1988; Omar \& Safinas, 2016) and problem solving (Mayer, 1992). However, one of the most famous definitions of CT is that of Facione (1990). He states that CT is a "purposeful, selfregulatory judgment that results in interpretation, analysis, evaluation, and inference, as well as explanation of the evidential, conceptual, methodological, criteriological, or contextual considerations upon which that judgment is based" (p. $3)$.

In the following section, the status of CT in Saudi Arabia will be examined against the backdrop of current religious and educational realities.

\section{Critical Thinking in the Religious and the Educational Context of Saudi Arabia}

\subsection{The Islamic Perspective on Critical Thinking}

CT as a complex cognitive practice has been often considered a privilege limited to Western contexts where CT is a cultural norm. Atkinson (1997), for instance, claims that CT is only applicable in Western contexts. However, the words of Prophet Muhammad (Peace be upon him.), as understood from the Islamic instructions derived from the Holy Quran, rigorously disputes this claim. Thinking is even elevated to the status of an Islamic religious duty or obligation (Alaqqad, 2014).

To begin with, Islam has encouraged thinking as a path for recognizing the Almighty's existence and as a way to recognize His powers and wisdom. Thus, using one's senses to observe His creations requires CT in order that one may analyze, synthesize and reflect. He says, "Say: Travel through the earth and see how Allah did originate creation; so will Allah produce a later creation, for Allah has power over all things" (Quran 29: 30) (Al-Nofaie, 2013). Another example of how Allah encourages thinking is, in His words, "Do they look at the camels, how they are made? And at the sky, how it is raised high? And at the mountains, how they fixed form? And at the earth, how it is spread out? Therefore do remind for thou art one to remind." (Quran 88: 17-21). In fact, the Quran includes numerous verses that promote thinking, according to Jrowan (1999, cited in Alturki, 2013, p.18), as quoted here: 
- The number of verses that articulate words originated from the word "Al Aql" in Arabic meaning "intellect" are 49 verses.

- The number of verses calling for "Alnathar" meaning 'the use the sense of seeing to consider, mediate, reflect' are 129.

- The number of verses calling for "Attadabbur" meaning 'the act of mediation, speculation, reflection' are 148.

- The number of verses calling for "Attafakkur" meaning to 'contemplate, consider carefully, works one's mind' are 16.

Moreover, Islam praises people who think and reflect on natural phenomena. Allah says in the Qur'an, "Lo! In the creation of the heavens and the earth and (in) the difference of night and day are tokens (of His sovereignty) for men of understanding. Such as remember Allah, standing, sitting, and reclining, and consider the creation of the heavens and the earth, (and say): Our Lord! Thou created not this in vain. Glory be to Thee! Preserve us from the doom of Fire" (Quran 3: 190, 191) (Cited in Qasmi, n.d., para. 13). Similarly, Prophet Muhammad (Peace be upon Him.) said: "The privilege of a scientist over that of a worshiper is like the privilege of the full moon over all other planets, indeed, the scientists are the inheritors of prophets."

Finally, as Qasmi (n.d.) states:

Islam allows critical thinking in other matters. The four major schools of thought in Islamic Fiqh, i.e., Hanafi, Shaf'ee, Maliki, Hanbli, are the clear proof of this claim. The scholars, having deep knowledge of the Glorious Qur'an, Hadith and Islamic sciences, discussed these matters, which were not explicitly mentioned in the Qur'an and Hadith, and they perform Ijtihad.

(para.5)

\subsection{Critical Thinking in Saudi EFL Contexts}

The status of English as an international language is the result of many historical, political, social, and economic factors. As a result of its status, English is a widely studied language and the medium of teaching in many countries around the globe. The Kingdom of Saudi Arabia (hereafter, KSA) is no exception. English is the mostcommonly taught and learned second or foreign language in Saudi Arabia. "During the Saudi Era, English and French were introduced to the secondary education system as foreign languages (Al-Abdulkader 1978). In 1958, the teaching of English and French began in the newly established intermediate level education system" (Mahboob \& Elyas, 2014). Accordingly, a deep-rooted relationship links the Saudi identity and English language. One example is that there is a new term to describe this 'hybrid' bond and that is the term "Saudi English" (Mahboob \& Elyas, 2014, p. 129).

However, based on the researcher's personal observation, although English language is taught from the age of ten in Saudi Arabia, many students are still inefficient in 
communicating in English when they reach institutions of higher education. At the university level, in the preparatory year, students are required to take a language placement test and the majority of them are placed at beginner levels. Cameron (2011) claims that given the fact that the government dedicates billions of Riyals to various service sectors, including education, in order to transform its population and economy, one must contemplate why the performance of the students is below expectations. He adds that, "In order for a country to develop both economically and socially it is necessary that citizens are provided with the skills and opportunities to locate, discuss, and solve problems...the majority of youth in the country are not equipped with critical thought skills or provided the opportunities to display dissatisfaction" (p.1).

Although strategies to encourage CT are finding their way into the pedagogy of various disciplines in Saudi Arabia, still their operationalization relies on the teachers. Unfortunately, teachers are instead encouraging memorization and shallow understanding of materials (Alhammad, 2010). This traditional approach to teaching does not permit efficient learning, particularly in the field of language learning. In fact, we can attribute many of Saudi EFL learners' difficulties to such a traditional approach to teaching (Khan, 2011). However, the obstacles to implementing CT pedagogy inside classrooms in Saudi Arabia are many. Alwadai (2007), in his Ph.D. research, listed seven obstacles to improving the CT skills of young people in Saudi schools. Among these obstacles are the students' ability, teaching methods and classroom structure (size and number of students). In addition, the Saudi society is one of the obstacles. According to Alwadai, it devalues CT and still consider questioning people in authority as disrespectful. Also, the school community was found to be another obstacle in this study. School administrations and supervisors do not support CT. Other obstacles include pre-service teachers' preparation programs and in-service teacher professional programs which neglect CT instruction. Finally, the last obstacle found was the curriculum. According to the study, the current curriculum is not appropriate to develop CT and stresses instead memorizing facts.

The following section provides a detailed background on the status and the potential of CT in the Saudi EFL context

\section{The Benefits of Fostering Critical Thinking in EFL Contexts}

Several studies have proposed that the use of CT pedagogy can facilitate L2 learning. Hashemi (2012) examined the relationship between overall CT abilities and proficiency of English language receptive skills. A significant correlation was observed between students' CT abilities and their language proficiency scores. Similarly, a significant correlation has been noted between the CT abilities of TOEFL test takers and their scores on the reading section of the test (Kamali, 2011).

In addition, similar studies have examined the effect on the receptive skills of using strategies that encourage CT. For instance, Auerbach and Paxton (1997) explored the effect of 'reflection' on EFL learners' awareness of their learning in a reading program and found that it increased awareness. Zhang (2010) found that demonstrating metacognitive abilities was effective in raising reading 
comprehension. Goh and Taib (2008) provided instruction designed to enhance metacognitive abilities and found there was significant improvement a listening post-test as a result. Other studies have found significant improvement in learners' speaking proficiency as a result of encouraging CT. Alnofaie (2013), in her Ph.D research, designed and implemented CT pedagogy in a Saudi EFL institute. Among the findings of her research, the effectiveness of CT in developing the participants' speaking abilities was evident. Similarly, applying a HOTS approach by giving EFL learners thinking lessons, aided development of their speaking proficiency (Chen, 2010).

Further, some researchers have investigated the effect of CT on vocabulary learning. A study entitled 'Applying cognitive science principles to improve retention of science vocabulary' has investigated the relationship between size of science vocabulary and drawing pictures and talking about the definitions of the terms (Shore \& Ray \& Gooklasian, 2015). Their findings demonstrated significant improvement in vocabulary retention post-tests. Another study that relates CT and vocabulary in EFL learning is Kamali's and Fahim's (2011) empirical study. In their study, a significant relationship was noted between three variables: learners CT abilities, their resilience, and their ability to read texts with unfamiliar vocabulary.

Other studies have attributed further benefits to the implementation of CT pedagogy in EFL instruction. For instance, fostering CT skills through creation of portfolios led to autonomous learning (Lo, 2010). Using CT skills led to female empowerment in other studies. For example, Fairley (2009) included debates among CT practices that led to female empowerment in mixed gender classroom participation. Finally, some studies have demonstrated gains in the overall academic performance of learners after they receive CT lessons (Yang \& Chung, 2009).

After demonstrating the benefits of fostering CT, various strategies to promote its incorporation into Saudi classroom activities are discussed.

\section{Promoting Critical Thinking in EFL Saudi Contexts}

The importance of $\mathrm{CT}$ as a teaching pedagogy has been recognized in many disciplines. In the field of EFL, many studies have been conducted to investigate CT in EFL classrooms. The main goal of several studies has been to investigate how to foster CT in EFL learners. Rezaei (Rezaei Derakhshan \& Bagherkazemi, 2011) reviewed the teachability of CT. Their review represents a rich resource for CT techniques that may be used in classrooms, such as debates, media analysis and problem-solving tasks. All these are claimed to foster CT. Similarly, Tabrizi (2011) measured the effect of an intervention based on reading skills activities on EFL learners' CT skills. His results showed that students' CT skills were enhanced. Additionally, Park (2011) reported the benefits and the challenges of using authentic materials such as newspapers articles in a reading curriculum to develop learners' CT skills.

Other studies have tried promoting CT with the aid of computer technology. Duad $\&$ Husin (2004) observed the role of computer reading software in developing CT. In this research study, the experimental group outperformed the control group, 
which indicates that the use of this technology can develop EFL learners' CT skills. Similarly, using an internet-based intervention, Chiu (2009) confirmed that the development of Taiwanese EFL students' CT in a reading course was a result of participating in online discussions. Al Sharadgah (2014) conducted a study of using internet technology to develop learners' CT skills in Saudi settings. In his research, he developed a writing program in an internet-based environment with the aim of developing participants' CT skills. The students who used the program showed great improvement in their CT skills.

Besides investigating the roles of the various practices mentioned above, including technology-based ones, in developing CT abilities in EFL learners, the role of the teacher has been investigated. Li (2011) considered the teacher's role in hindering or obstructing students' use of HOTS (higher order thinking skills) in EFL classrooms. His study suggests that teachers can encourage learners to use HOTS through adopting certain practices, such as reducing interruptions and asking referential questions.

\section{Conclusion}

In the $21^{\text {st }}$ century, it is recognized that the role of education in communities goes beyond classroom boundaries. Nowadays, the responsibility of educational institutions is to equip individuals with the essential skills to achieve success in their lives and to facilitate success for their communities. CT skills are amongst the skills most in demand and most needing to be acquired and improved by learners. This is as true for the Saudi learner as all others. The religion in Saudi Arabia advocates CT. However, there are several barriers to adequate CT implementation in the Saudi EFL context, being part of the general educational context. In addition to acknowledging the benefits of CT in TEFL, serious attempts and strategic plans should be planned and executed to foster CT in EFL learners. Some practices to promote its implementation have been described in this paper.

\section{References}

Alaqqad, A. (2014). Attafker faridah Islamiah [Thinking is an Islamic religious duty]. Cairo: Iqra'a Corporation.

Alhammad, T. (2010). The education dilemma in Saudi Arabia. The Harvard Crimson. Retrieved November 2015 from http://www.thecrimson.com/article/2010/2/12/saudi-education-studentsschool/

Alnofaie, H. A. (2013). The implementation of critical thinking as EFL pedagogy: Challenges and opportunities (Doctoral dissertation, Newcastle University). Retrieved 22 October, 2015, from October 22 http://hdl.handle.net/10443/2326

Al Sharadgah, A. (2014). Developing critical thinking skills through writing in an internet-based environment, Pertanika, 4(1), 169-178.

Alturki, S. (2013). Kunn Mufakran [Be a Thinker]. Riyadh: King Fahad National Library. 
Alwadai, M. (2014). Islamic teachers' perceptions of improving critical thinking skills in Saudi Arabian elementary schools (Doctoral dissertation, Southern Illinois University Carbondale). Retrieved October 22, 2015, from http://opensiuc.lib.siu.edu/dissertations/882

Auerbach, E. and Paxton, D. (1997). It's not the English thing: Bringing reading research into the ESL classroom, TESOL Quarterly, 31(2), pp. 237-261.

Bender, T. (2003). Discussion-based Online Teaching to Enhance Student Learning: Theory, practice and assessment. Sterling: Stylus.

Beyer, B. K. (1988). Developing a thinking skills program. Boston, MA: Allyn \& Bacon, Inc.

Cameron, B. (2011). Critical thoughts on critical thinking in Saudi Arabia. Open Democracy. $\quad$ Retrieved November 2015, from https://www.opendemocracy.net/bobby-thomas-cameron/critical-thoughts-oncritical-thinking-in-saudi-arabia

Chen, M. (2010). Infusing thinking skills into an L2 classroom: a case study of an innovation in a Taiwanese university (Doctoral dissertation, Newcastle University). Retrieved October, 2015, from http://hdl.handle.net/10443/1570

Chiu, Y.C. (2009). Facilitating Asian students' critical thinking in online discussions, British Journal of Educational Technology, 40(1), 42-57.

Daud, N. and Husin, Z. (2004). Developing critical thinking skills in computer-aided extended reading classes, British Journal of Educational Technology, 35(4), 477-487.

Ennis, R. (1996) Critical Thinking. Upper Saddle River, NJ: Prentice-Hall.

The Delphi Report. (1999). Report of Research Finding and Recommendations Panel. Critical thinking: A statement of expert consensus for purposes of educational assessment and instruction panel. Retrieved October 22, 2015 from http://eric.ed.gov/?id=ED315423

Fairley, M.J. (2009). 'De-silencing female voices: the use of controversial debate topics in the EFL classroom', in Wachob, P.E. (ed.) Power in the EFL classroom: critical pedagogy in the Middle East. Newcastle Upon Tyne: Cambridge Scholars Publishing, 55-73.

Gashan, A. K. (2015). Exploring Saudi pre-service teachers' knowledge of critical thinking skills and their teaching perceptions. International Journal of Education and Literacy Studies, http://doi.org/10.7575/aiac.ijels.v.3n.1p.26

Goh, C. and Taib, Y. (2006). Metacognitive instruction in listening for young learners, ELT Journal, 60(3), 222-232.

Hashemi, M. and Ghanizadeh, A. (2012). Critical discourse analysis and critical thinking: an experimental study in an EFL context, System, 40(1), 37-47.

Hedge, T. (2000). Teaching and learning in the language classroom: A guide to current ideas about the theory and practice of English language teaching. Oxford: Oxford University Press, USA.

Kamali, Z., \& Fahim, M. (2011). The relationship between critical thinking ability of Iranian EFL learners and their resilience level facing unfamiliar vocabulary 
items in reading. Journal of Language Teaching and Research, 2(1), 104-111. http://doi.org/10.4304/jltr.2.1.104-111

Khan, I. (2011). Learning difficulties in English: Diagnosis and pedagogy in Saudi Arabia. sInternational Research Journal, Educational Research, 2(7), 12481257.

Li, Li. (2011). Obstacles and opportunities for developing thinking through interaction in language classrooms, Thinking Skills and Creativity, 6, 146-158.

Lo, Y.F. (2010). Implementing reflective portfolios for promoting autonomous learning among EFL college students in Taiwan, Language Teaching Research,14(1), 77-95.

Mahboob. A. \& Elyas. T. (2014). English in the Kingdom of Saudi Arabia. World Englishes, 33(1), 128-142.

Mayer, R. (1992). Thinking, problem solving, cognition. New York: Freeman.

Omar, A. \& Safinas M. A.A., Intan. (2016). Thinking Maps to Promote Critical Thinking through the Teaching of Literature in the ESL Context. IJELTAL (Indonesian Journal of English Language Teaching and Applied Linguistics), 1(1), 2016

Oxford University Press ELT. (2013). Critical thinking in your lessons-It's easier than you think! [Web log post]. Retrieved October 2015, from http://oupeltglobalblog.com/2013/10/09/critical-thinking-in-your-lessons-itseasier-than-you-think/

P21 Partnership for $21^{\text {st }}$ Century Learning (2009). Framework for $21^{\text {st }}$ Century Learning. Retrieved November 22, 2015, from http://www.p21.org/aboutus/p21-framework

Park, Y. (2011). Using news articles to build a critical literacy classroom in an EFL setting, TESOL Journal, 2(1), 24-51.

Qasmi, M.(n.d). Does Islam permit critical thinking? Retrieved November 2015, from http://www.irfi.org/articles/articles_351_400/does_islam_permit_critic al_think.htm

Rezaei, S., Derakhshan, A., \& Bagherkazemi, M. (2011). Critical thinking in language education. Journal of Language Teaching and Research, 2(4), 769777. http://doi.org/10.4304/jltr.2.4.769-777

Shore, R., Ray, J., \& Gooklasian, P. (2015). Applying cognitive science principles to improve retention of science vocabulary. Learning Environments Research, 233-248. http://doi.org/10.1007/s10984-015-9178-1

Tabrizi, A.R.N. (2011). Critical thinking and EFL learners' reading, in INTED2011 Proceedings: 5th International Technology, Education and Development Conference, 7-9 March 2011,Valencia, Spain, pp. 2689-2699. Retrieved October 2015 , from http://library.iated.org/?search_text=publication\%3AINTED2011

Yang, S. and Chung, T. (2009). Experimental study of teaching critical thinking in civic education in Taiwanese junior high school. British Journal of Educational Psychology, 79, 29-55. 
Al Zahrani \& Elyas, The Implementation of Critical Thinking in a Saudi EFL Context

Zhang, L. (2010). A dynamic metacognitive systems account of Chinese university students' knowledge about EFL reading. TESOL Quarterly, 44(2), 320-353. 